\title{
miR-194 is a negative regulator of GEF-H1 pathway in melanoma
}

\author{
BINGYU GUO, QIANG HUI, YU ZHANG, PENG CHANG and KAI TAO
}

\author{
Reconstructive and Plastic Surgery, The General Hospital of Shenyang Military Region, \\ Shenhe, Shenyang, Liaoning 110016, P.R. China
}

Received March 18, 2016; Accepted August 1, 2016

DOI: 10.3892/or.2016.5020

\begin{abstract}
The incidence and associated mortality of melanoma continues to increase worldwide. At present, there is no curative therapy for advanced stage of melanoma. It is necessary to find new indicators of prognosis and therapeutic targets. Increasing evidence shows that miRNA can provide potential candidate biomarkers for melanoma and therapeutic targets. GEF-H1, a regulator of RhoA, as oncogenic driver in melanoma, promotes the growth and invasion of melanoma. miR-194 is a tumor-suppressor gene in multiple tumors, such as bladder and non-small cell lung cancer, and clear cell renal cell carcinoma. In the present study, we demonstrated that GEF-H1 serves as target of miR-194. Overexpression of miR-194 downregulates the GEF-H1/RhoA pathway, inhibits melanoma cancer cell proliferation and metastasis. Furthermore, miR-194 expression is negatively associated with tumor-node-metastasis (TNM) stages. Briefly, our findings provided new theoretical basis for melanoma treatment.
\end{abstract}

\section{Introduction}

Melanoma is a common malignant tumor, and the most aggressive form of skin cancer, which incidence keeps increasing worldwide (1). Despite expectations that targeted therapies based on mutations intended to improve the survival of patients, current regiments are not satisfactory (2). New therapies, including mitogen-activated protein kinase (3) pathway inhibitors, such as BRAF and MEK inhibitors, as well as other signaling pathways inhibitors, are being tested in metastatic melanoma either as immunotherapy or in combination, and have yielded promising results (4). However, we still need to find novel targets for treatment of melanoma.

Correspondence to: Dr Kai Tao, Reconstructive and Plastic Surgery, The General Hospital of Shenyang Military Region, 83 Wenhua Road, Shenhe, Shenyang, Liaoning 110016, P.R. China E-mail: luzongzhengxing@sina.com

Key words: GEF-H1, melanoma, prognosis, proliferation, metastasis
Rho guanine nucleotide exchange factor (5) is a protein which regulates the activity of Rho GTP enzyme through regulating the exchange of GDP/GTP (6). GEF-H1 has a wide range of biological functions, such as regulating vesicle transport and cell movement (6,7), stabling cytoskeleton (8), affecting the cell barrier function (9-12), promoting cell cycle progression and inhibiting cell apoptosis and other biological functions $(5,10,12-15)$. GEF-H1 has been reported to have abnormal activation in many types of cancers, such as breast, prostate and myeloid cell cancer $(10,16-20)$. There are also several studies showing that GEF-H1 was overexpressed in brain metastatic melanoma (12). GEF-H1 induces the activation of RhoA oncogene (21-23), and then activates various signals pathways, such as proliferation, metastasis and cytoskeleton reorganization (24).

MicroRNA (miRNA) is an endogenous short chain RNA with a length of $\sim 22 \mathrm{nt}$. Through endogenous RNA interference machinery they can repress multiple target genes (25-27). In a variety of cancers, the prognosis of patients was considered to be close to the expression of miRNAs. Increasing reports show that miRNAs played important roles in cell differentiation, individual development, cell growth and metastasis (28). Muller and Bosserhoff found that several of the miR-let-7 family members had decreased expression in melanoma and miR-let-7a reduced NRAS expression in melanoma (29). In melanoma miR-193b has been reported to be downregulated with overexpression of cyclin D1; then, promoting the proliferative capacity of melanoma (30). Also it was demonstrated that cancer growth was reduced when miR-205 was overexpressed $(31,32)$. All these studies indicated that miRNA regulates multiple targets then affect the biological functions of melanoma cells.

miR-194 has been reported to suppress invasion and migration of liver cancer cells (33). Experiments showed that miR-194 has a low expression in colon cancer (34). Previous research showed that miR-194 expression was associated with the advanced stage in gastric cancer (35). However, there is no previous study concerning the expression and function of miR-194 in melanoma.

In the present study, we studied the expression of miR-194 and GEF-H1 in melanoma using real-time PCR, and investigated the association between miR-194 and GEF-H1. Results showed that miR-194 had a negative correlation with the tumor-node-metastasis (TNM) stage of melanoma, and it 
Table I. The primer sequences used in the experiments.

\begin{tabular}{lll}
\hline Name & \multicolumn{1}{c}{ Forward primer $\left(5^{\prime} \geq 3^{\prime}\right)$} & \multicolumn{1}{c}{ Reverse primer $\left(5^{\prime} \geq 3^{\prime}\right)$} \\
\hline miR-194 & ACACTCCAGCTGGGCCAGTGGGGCTGC & $\begin{array}{l}\text { CTCAACTGGTGTCGTGGAGTCGG } \\
\text { CAATTCAGTTGAGCAGATAAC }\end{array}$ \\
U6 & CTCGCTTCGGCAGCACA & AACGCTTCACGAATTTGCGT \\
GEF-H1 & GAGTGCTTTAGGCCGCTTG & GACCTTGGTACAGTTGGCG \\
RhoA & GTCCACGGTCTGGTCTTCAG & GTGTCCCACAAAGCCAAC \\
p21 & GTGGCTATTTTGTCCTTGGG & GGCGCCTGAACAGAAGAAA \\
Ecad & GGAGGCTCTCCCGTCTTTTG & CTTTGTCGACCGGTGCAATC \\
vim & GGACCAGCTAACCAACGAC & GGTCAAGACGTGCCAGAG \\
GAPDH & CTCTGCTCCTCCTGTTCGAC & GCGCCCAATACGACCAAATC \\
\hline
\end{tabular}

suppresses the growth and metastasis of melanoma cells by downregulating the expression of GEF-H1.

\section{Materials and methods}

Tissue samples and cell lines. We obtained 60 paired samples of tumor and adjacent normal tissues from patients with melanoma in the General Hospital of Shenyang Military Command. The protocols were approved by the Ethics Committee of the General Hospital of Shenyang Military Command. All cases were diagnosed with melanoma and treated between January 2009 and December 2009 at the General Hospital of Shenyang Military Command. The case details are shown in Table II.

Laser capture microdissection was performed on melanoma tumors that were selected when tumor blocks were readily available for the tissue sectioning required for laser capture microdissection (36).

A375 was purchased from the American Type Culture Collection (ATCC; CRL-1619; Manassas, VA, USA) and A875 was purchased from Shanghai Maisha Biotech. Cells were cultured in Dulbecco's modified Eagle's medium (DMEM) supplemented with $10 \%$ fetal bovine serum (FBS) (HyClone, Logan, UT, USA) at $37^{\circ} \mathrm{C}$ under $5 \% \mathrm{CO}_{2}$.

MTT assays. Cells were seeded at a density of $1 \times 10^{3}$ cells/well of 96-well plates, and transfected with miR-194 mimic (AUGG UGUUAUCAAGUGUAACAGCAACUCCAUGUGGACUG UGUACCAAUUUCCAGUGGAGAUGCUGUUACUUUUG AUGGUUACCAA), miR-194 inhibitor(UCCACAUGGAGUU GCUGUUACA) or negative control (UCACAACCUCCUAGA AAGAGUAGA); $12 \mathrm{~h}$ later, the cell proliferation was evaluated by MTT assay. Microplate reader (Bio-Rad, Hercules, CA, USA) was used to measure the optical densities at $490 \mathrm{~nm}$.

Transwell assay. The Matrigel invasion chamber was used to assess cell invasion ability (24-well plates, $8-\mu \mathrm{m}$ pore size; Corning, Corning, NY, USA). In brief, $1 \times 10^{5}$ cells in serumfree media were seeded in Transwell chambers with Matrigel membranes covered or uncovered with the media containing $0.1 \%$ bovine serum albumin, while the media containing $30 \%$ FBS was placed in the lower well. Twenty-four hours after transfection with miR-194 mimic, miR-194 inhibitor or negative control cells, the non-invading cells were removed with cotton swabs. Cells at the bottom of the membrane were stained with $0.1 \%$ crystal violet and were counted by microscopy.

Quantitative real-time PCR. Total RNA from tissue samples and cells was extracted by TRIzol (Invitrogen, Carlsbad, CA, USA) through the protocol. Real-time PCR was carried out using Real-time PCR Universal reagent and the MX3000P real-time PCR instrument following the protocols. The expression of miR-194 was detected by stem-loop RT-PCR assay as previously reported $(37,38)$. The primers are shown in Table I. All the reactions were carried out as previously described (39).

Western blot analyses. The cells and tissues were lysed in lysis buffer (25 mM Tris, pH 7.6, $150 \mathrm{mM} \mathrm{NaCl,} \mathrm{1 \%} \mathrm{Nonidet} \mathrm{P-40,}$ $1 \mathrm{mM}$ EDTA), supplemented with proteinase and phosphatase inhibitors (Sigma-Aldrich, St. Louis, MO, USA). The cell lysates were fractionated by $10 \%$ SDS-PAGE, and were transferred to a polyvinylidene difluoride membrane (Millipore Corporation, Billerica, MA, USA). Target proteins were probed with specific antibodies: GEF-H1 (sc-134827), RhoA (sc-119), p21 (sc-21532), Ecad (sc-21791), vim (sc-80975) and GAPDH (sc-365062) (Santa Cruz Biotechnology, Santa Cruz, CA, USA).

Dual-luciferase reporter assay. Dual-luciferase activity assays were performed as previously described (40). The GEF-H1 3'-untranslated region (3'-UTR) was PCR amplified and cloned into the pMIR-REPORT ${ }^{\mathrm{TM}}$ vector (Ambion, Carlsbad, CA, USA). The primers used were: GEF-H1-WT F, 5'-CCCGTC CGATTATGTCTCGG-3' and R, 5'-GCTGTCGGAGGGGT AG-3'; GEF-H1-DEL F, 5'-CCCGTCCGATTATGTCTCGG-3' and R, 5'-CGCCCCCTCACATGGTGC-3'. A375 cells were seeded into 24-well plates and co-transfected with $500 \mathrm{ng}$ WT or DEL reporter vector and $10 \mathrm{ng}$ pMIR-REPORT ${ }^{\mathrm{TM}}-\beta g a l$ control plasmid in miR-194 mimic and miR-194 AS. Luciferase activity was determined using the dual-luciferase reporter assay system after $36 \mathrm{~h}$ transfection; the luciferase activity was measured using the Dual-luciferase Reporter Assay System (Promega, Madison, WI, USA). 
Table II. The relationship between miR-194 and melanoma.

\begin{tabular}{|c|c|c|c|c|c|c|}
\hline \multirow[b]{2}{*}{ Variables } & \multirow[b]{2}{*}{ Description } & \multirow[b]{2}{*}{ No. of patients } & \multicolumn{2}{|c|}{ miR-194 expression } & \multirow[b]{2}{*}{$\chi^{2}$} & \multirow[b]{2}{*}{ P-value } \\
\hline & & & Low & High & & \\
\hline \multirow[t]{2}{*}{ Gender } & Male & 26 & 21 & 10 & \multirow[t]{2}{*}{0.630} & \multirow[t]{2}{*}{0.202} \\
\hline & Female & 34 & 30 & 9 & & \\
\hline \multirow[t]{2}{*}{ Age (years) } & $<55$ & 29 & 22 & 7 & \multirow[t]{2}{*}{3.794} & \multirow[t]{2}{*}{0.051} \\
\hline & $\geq 55$ & 31 & 16 & 15 & & \\
\hline \multirow[t]{2}{*}{ Primary tumor ulceration } & With & 38 & 20 & 18 & \multirow[t]{2}{*}{5.111} & \multirow[t]{2}{*}{$0.024^{\mathrm{a}}$} \\
\hline & Without & 22 & 18 & 4 & & \\
\hline \multirow[t]{2}{*}{ Tumor thickness } & $<4 \mathrm{~mm}$ & 31 & 15 & 16 & \multirow[t]{2}{*}{6.170} & \multirow[t]{2}{*}{$0.013^{\mathrm{a}}$} \\
\hline & $>4 \mathrm{~mm}$ & 29 & 23 & 6 & & \\
\hline \multirow[t]{2}{*}{ Family history } & No & 48 & 31 & 17 & \multirow[t]{2}{*}{0.161} & \multirow[t]{2}{*}{0.688} \\
\hline & Yes & 12 & 7 & 5 & & \\
\hline \multirow[t]{4}{*}{ TNM grade } & I & 22 & 18 & 4 & \multirow[t]{4}{*}{8.012} & \multirow[t]{4}{*}{$0.046^{\mathrm{a}}$} \\
\hline & II & 20 & 8 & 12 & & \\
\hline & III & 12 & 8 & 4 & & \\
\hline & IV & 6 & 4 & 2 & & \\
\hline
\end{tabular}

Association between the expression of miR-194 with clinicopathological features in patients with melanoma. Through the Chi-square test we found there was little correction between miR-194 with the gender, age or family history. However there was correction between the miR-194

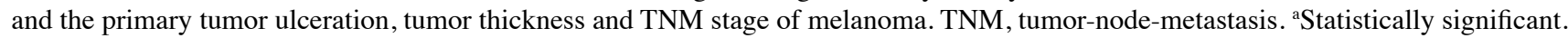

Immunofluorescence staining. All the reactions were carried out as previously described (41). Briefly, $\sim 4-\mu \mathrm{m}$ thick slices were cut from paraffin-embedded specimens, and IHC staining was performed on tissue slices. These sections were treated at $80^{\circ} \mathrm{C}$ for $30 \mathrm{~min}$, deparaffinized with xylene and rehydrated after washing with different alcohol concentrations. All dewaxed slices were immersed in $0.01 \mathrm{mmol} / 1$ citrate buffer (pH 6.0) and maintained in high-pressure steam at $121^{\circ} \mathrm{C}$ for $4 \mathrm{~min}$ to fix antigenicity. Afterwards, the slices were cooled to room temperature. To remove the endogenous peroxidase activity, the slices were placed in $3 \%$ hydrogen peroxide for $10 \mathrm{~min}$. Tissue sections were incubated with GEF-H1 antibody (sc-134827) (1:200) at $4^{\circ} \mathrm{C}$ overnight, washed three times (5 min each) with phosphate-buffered saline, and finally incubated with biotin-labeled secondary antibody and horseradish peroxidase-conjugated streptavidin for $20 \mathrm{~min}$. All slices were immersed in 3,3'-diamino-benzidine tetrahydrochloride (Dako Corporation, Glostrup, Denmark) at $37^{\circ} \mathrm{C}$, which was followed by hematoxylin counterstaining.

Statistical analysis. In the present study $\chi^{2}$ test was used to analyze the relationship between miR-194 and clinicopathological variables. A univariate analysis of log-rank test was used to evaluate the differences among the levels of possible prognostic factors. All the data were analyzed with SPSS 17.0 (SPSS, Inc., Chicago, IL, USA). Statistical significance was defined as $\mathrm{p}<0.05$. All experiments were repeated three times.

\section{Results}

Expression of GEF-H1 in melanoma tissues. In order to study the relationship between GEF-H1 and melanoma, we detected the expression of GEF-H1 in tumor and adjacent tissues by real-time PCR, western blotting and immunofluorescence staining (Fig. 1A, B and E). The adjacent tissues were used as a control. Results showed that there was a higher expression of GEF-H1 in melanoma tissues than the adjacent tissues. Furthermore, in order to explore the relationship between GEF-H1 and melanoma, we selected melanoma tissues of different TNM stages to test the expression of GEF-H1 by real-time PCR, western blotting and immunofluorescence staining (Fig. 1C, D and F). We found that with the increase of TNM grade of melanoma, the expression of GEF-H1 was increased.

miR-194 inhibits the expression of GEF-H1 in A375 cells. miR-194 has been reported downregulated in various types of cancers (42), however, its expression in melanoma has not been reported. To test the expression of miR-194 in tumor and adjacent tissues, we used real-time PCR assay (Fig. 2A). We found that the expression of 194 in tumor tissues was lower than that in the adjacent tissues. Then, we classified 60 patients with melanoma according to the literature (43), and the results showed that the expression of miR-194 was correlated with TNM stage, primary tumor ulceration, tumor thickness and age of melanoma (Table II). It is concluded that miR-194 may have a certain effect on the occurrence and development of melanoma, and then through miRDB tool we found many proteins which can interact with miR-194 (Fig. 2B). After detailed analysis we concluded that the low expression of GEF-H1 in melanoma tissues may be related to miR-194. Since miR-194 could be combined with 3'-UTR of GEF-H1 (Fig. 2C). We confirmed our inference by the luciferase reporter assay, which showed that miR-194 can indeed reduce the expression of GEF-H1 at the transcriptional level (Fig. 2D). Results showed 

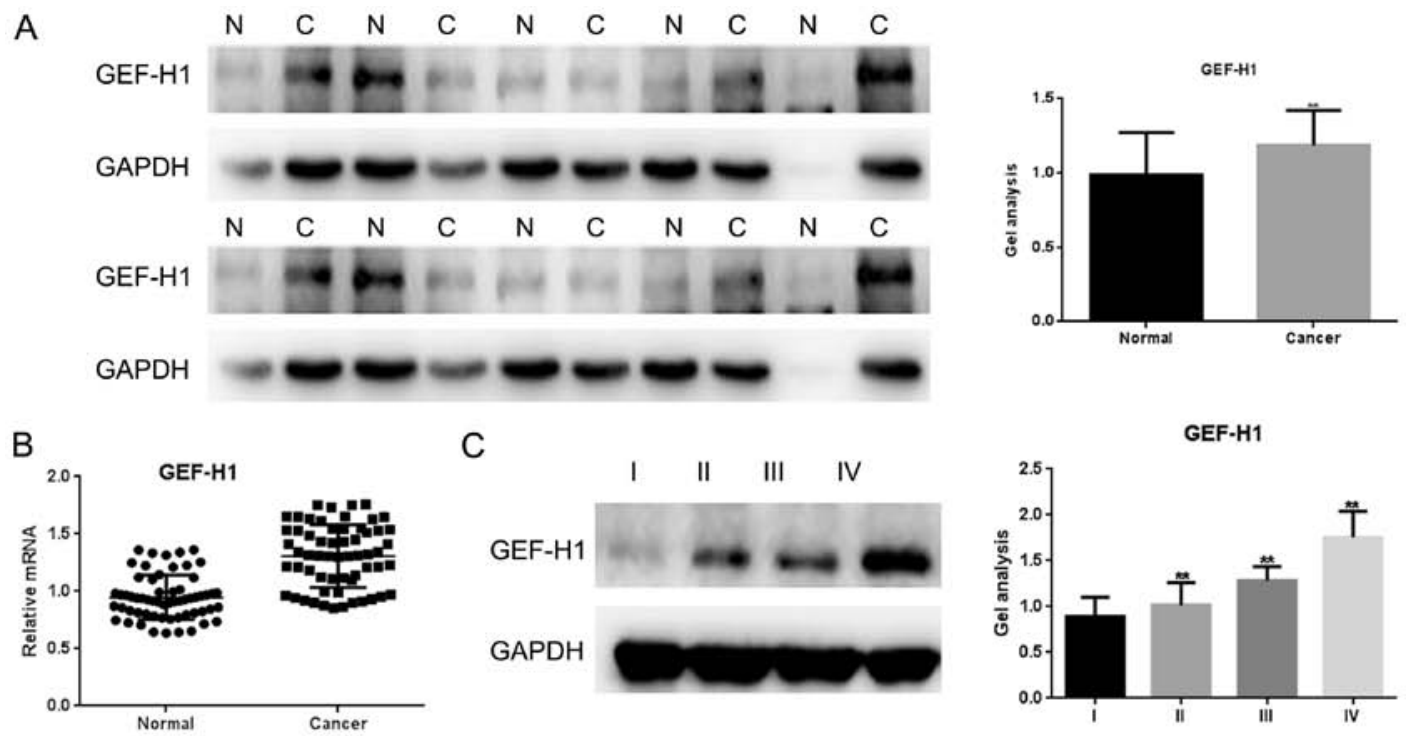

C
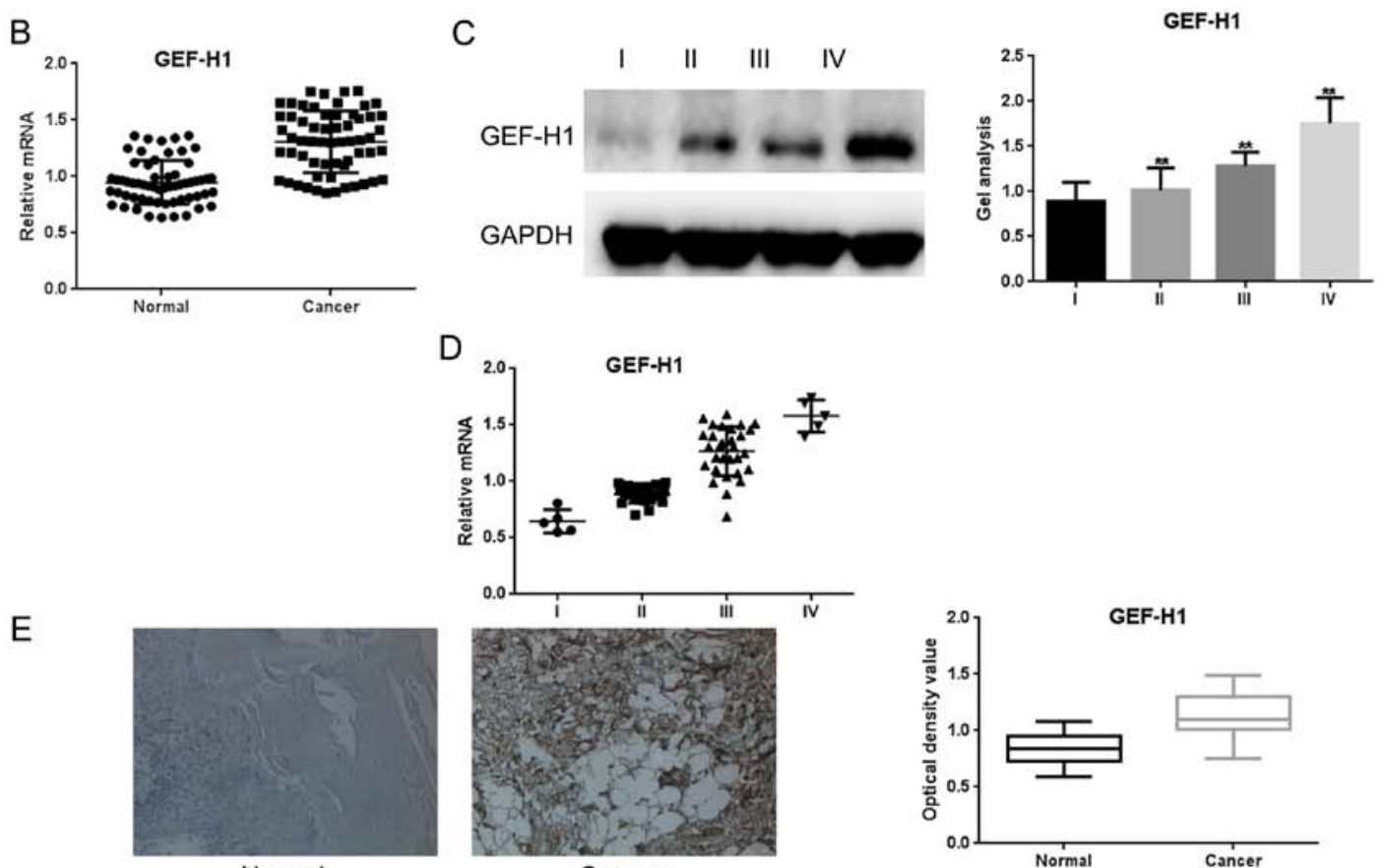

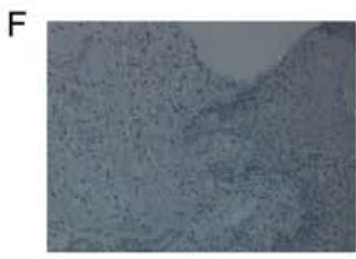

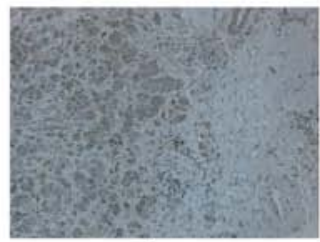

II

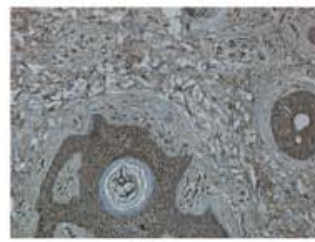

III

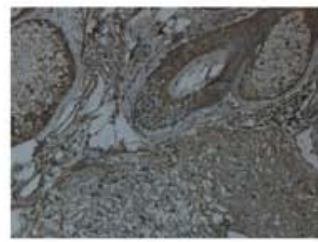

IV

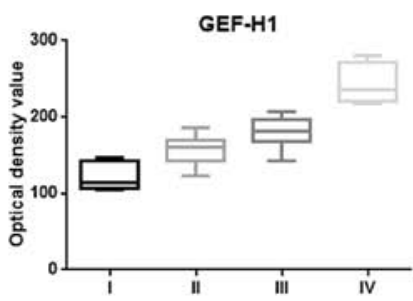

Figure 1. Expression of GEF-H1 in melanoma tissues. (A) The protein level of GEF-H1 expression in melanoma and adjacent tissues were detected using western blotting. The expression of GEF-H1 was higher in the melanoma tissues. Data are shown as mean \pm SEM; ${ }^{* *}$ p $<0.01$ vs. the adjacent tissues group. (B) mRNA expression of GEF-H1 in 60 samples of melanoma and adjacent tissues were respectively detected by real-time PCR. The expression of GEF-H1 was higher in the melanoma tissues. Data are shown as mean \pm SEM; ${ }^{* *}$ p $<0.01$ vs. the adjacent tissues group. (C) The protein levels of GEF-H1 expression in different TNM stages of melanoma tissues were detected using western blotting. The expression of GEF-H1 was increased with the TNM stages. Data are shown as mean $\pm \mathrm{SEM} ;{ }^{* *} \mathrm{p}<0.01$ vs. I stage. (D) mRNA level of GEF-H1 expression in different TNM stages of melanoma tissues were detected by real-time PCR. The expression of GEF-H1 was increased with the TNM stages. Data are shown as mean \pm SEM; ${ }^{* *}$ p $<0.01$ vs. I stage. (E) Immunofluorescence staining was used to test the expression of GEF-H1 in 60 samples of melanoma and adjacent tissues. The expression of GEF-H1 was higher in the melanoma tissues. Data are shown as mean $\pm \mathrm{SEM} ;{ }^{* *} \mathrm{p}<0.01$ vs. the adjacent tissues group. (F) Immunofluorescence staining was used to test the expression of GEF-H1 in different TNM stages of melanoma tissues. The expression of GEF-H1 was increased with the TNM stages. Data are shown as mean \pm SEM; ${ }^{* *}$ p $<0.01$ vs. I stage.

that when cells were co-transfected with GEF-H1-WT and miR-194 a lower luciferase activity was achieved, however, the cells co-transfected with EGFR-DEL or miR-194 antisense (AS) did not show significant variations. Furthermore, we 
A

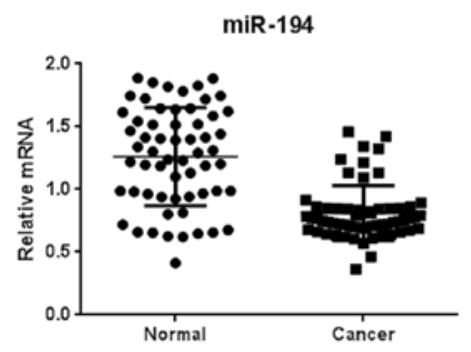

B

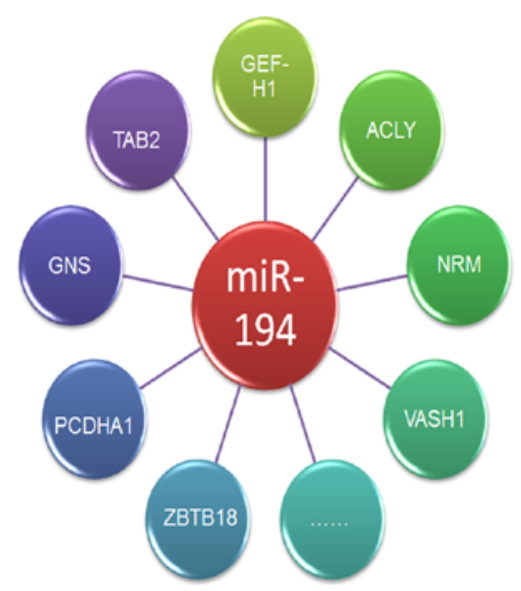

C

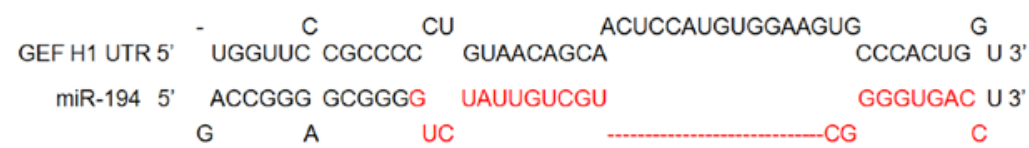

D

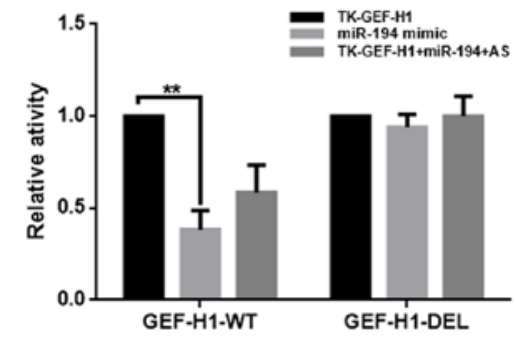

E Correlation analysis

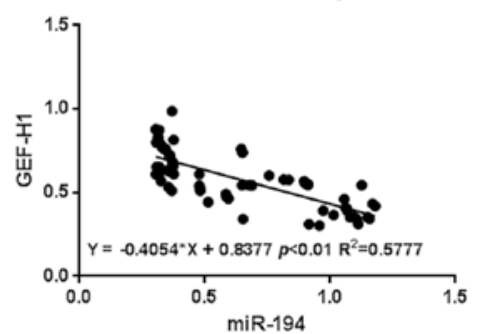

$\mathrm{F}$ Con miR-194 mimic

GEF-H1

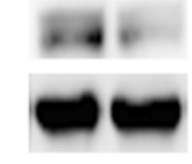

GAPDH

$\mathrm{H}$ Con miR-194 inhibitor

GEF-H1

GAPDH

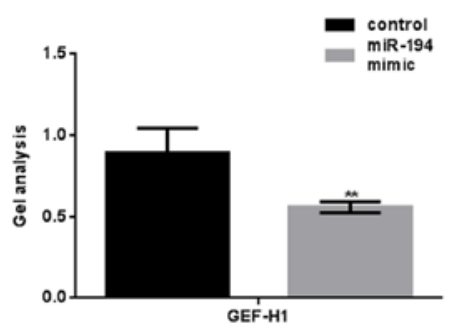

G
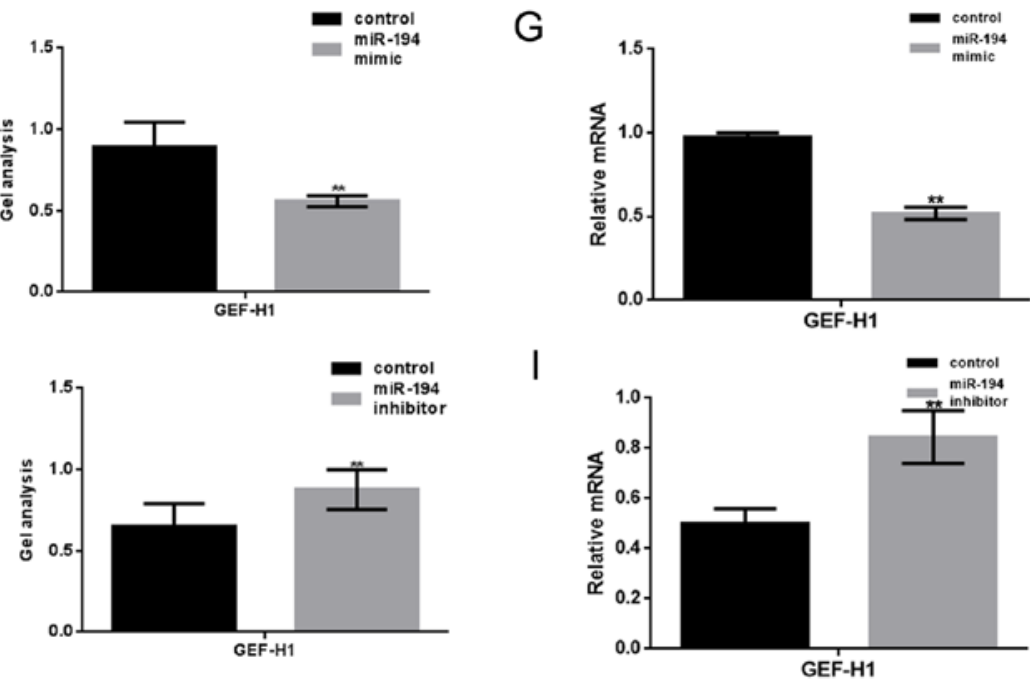

Figure 2. miR-194 inhibits the expression of GEF-H1 in A375 cells. (A) The levels of miR-194 in 60 samples of melanoma and adjacent tissues were detected by real-time PCR. There was lower expression of miR-194 in melanoma tissues. Data are shown as mean \pm SEM. ** $p<0.01$ vs. the adjacent tissues group. (B) Site prediction showed that miR-194 could target at a several of proteins. (C) miRDB predicted that miR-194 could specifically be combined with GEF-H1. (D) The interaction between miR-194 and the GEF-H1 3'-UTR was tested by luciferase reporter assays. Assays were performed by co-transfection of miR-194 or miR-194 antisense and WT-UTR or DEL-UTR. Data are shown as mean \pm SEM; ${ }^{* *}$ p $<0.01$ vs. the TK-GEF-H1 group. (E) Western blotting showed that when the miR-194 was overexpressed the expression of GEF-H1 was downregulated. Data are shown as mean \pm SEM; ${ }^{* *}<<0.01$ vs. the control group. (F-I) Real-time PCR showed the same result. Data are shown as mean \pm SEM; ${ }^{* *}$ p $<0.01$ vs. the control group. (G) Western blotting showed that when the miR-194 was repressed the expression of GEF-H1 was upregulated. Data are shown as mean $\pm \mathrm{SEM} ;{ }^{* *} \mathrm{p}<0.01$ vs. the control group. Data are shown as mean $\pm \mathrm{SEM} ;{ }^{* *} \mathrm{p}<0.01$ vs. the control group.

found there was a negative correlation between miR-914 and GEF-H1 in melanoma tissues (Fig. 2E). In order to further verify the relationship between miR-194 and GEF-H1, we transfected miR-194 mimic or miR-194 inhibitor into A375 cells. Then, we used real-time PCR and western blotting to detect the expression of GEF-H1 and miR-194 (Fig. 2F-I). Results showed that the expression of GEF-H1 was markedly downregulated by miR-194. 
A

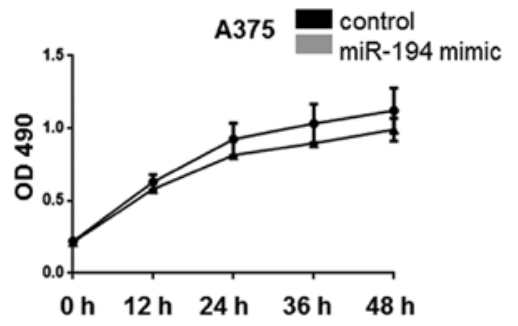

B

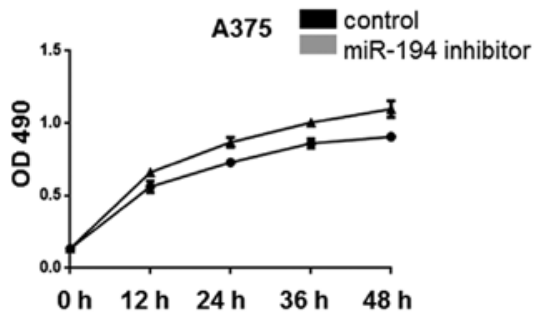

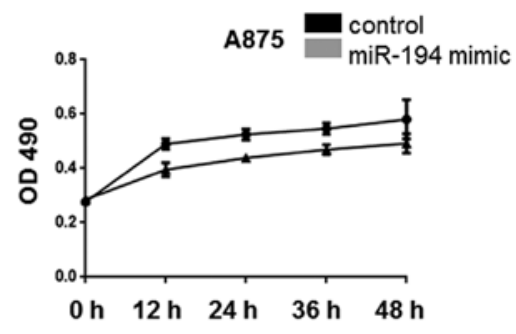

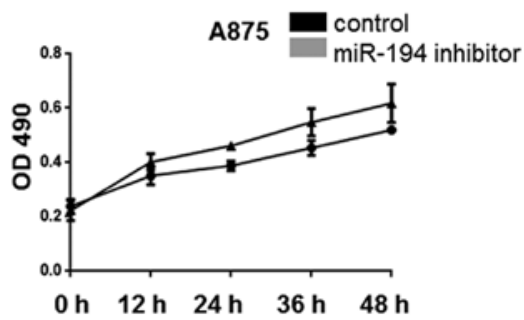

C

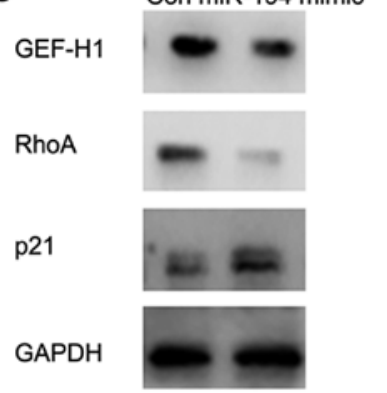

E

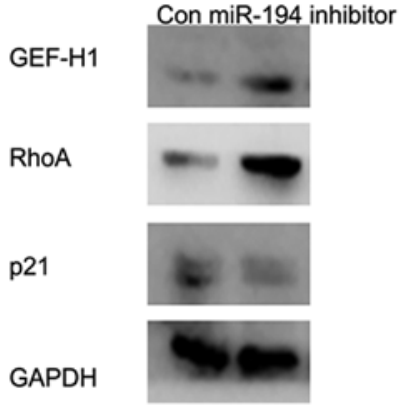

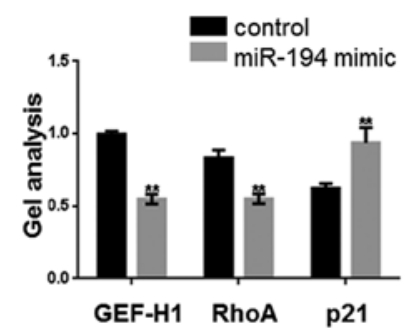

F

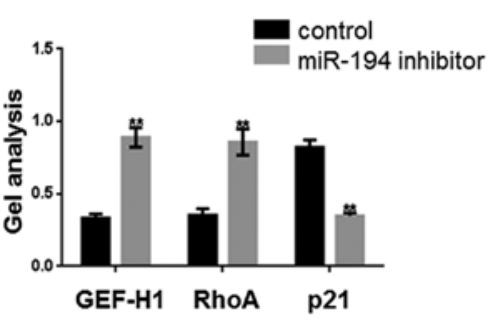

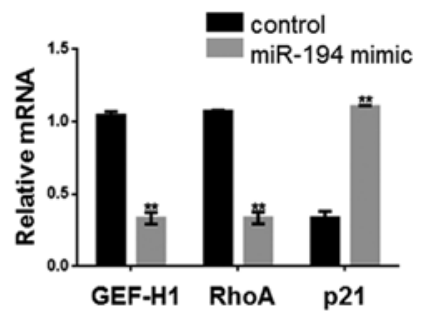

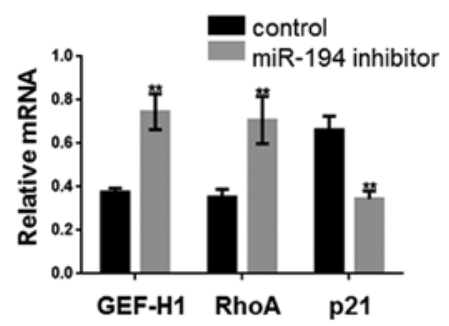

Figure 3. miR-194 inhibits the proliferation of melanoma cells by suppressing GEF-H1 pathway. (A) After transfected with miR-194 mimic A375 and A875 cell proliferation was repressed, which was detected by MTT assay. Data are shown as mean \pm SEM. (B) A375 and A875 cells were downregulated by miR-194, cell growth was detected by MTT assay. Data are shown as mean \pm SEM. (C and D) After transfection with miR-194 mimic in A375, the indicated proteins and mRNA were detected by western blotting and real-time PCR. Data are shown as mean \pm SEM; ${ }^{* *} p<0.01$. (E and F) After downregulation of miR-194, the indicated proteins and mRNA in A375 cells were detected by western blotting and real-time PCR. Data are shown as mean \pm SEM; $*$ p $<0.01$.

miR-194 inhibits the proliferation of melanoma cells by suppressing GEF-H1 pathway. Numerous studies have indicated that GEF-H1 promotes cell proliferation by regulating the expression of RhoA, thus, we wanted to investigate whether miR-194 regulates the proliferation of melanoma cells by affecting the GEF-H1/RhoA pathway. MTT assay was used to examine the effect of miR-194 on cell proliferation. The proliferation of A375 and A875 were significantly depressed by transfection with miR-194 mimic (Fig. 3A). On the contrary, when transfected with miR-194 inhibitor, we found promotion of cell proliferation (Fig. 3B). As known, p21 is an important downstream protein in GEF-H1/RhoA pathway. Thus, we overexpressed or downregulated miR-194 and then examined the expression of $\mathrm{p} 21$ by western blotting and real-time RT-PCR (Fig. 3C-F). Results showed that miR-194 can inhibit the expression of GEF-H1 and RhoA, but it significantly increased the expression of $\mathrm{p} 21$. Thus, the results showed that miR-194 negatively regulates GEF-H1, then inhibiting the proliferation of A375 by inhibiting the GEF-H1/RhoA pathway.

miR-194 inhibits the metastasis of melanoma cells by suppressing the GEF-H1/RhoA pathway. GEF-H1 affects metastasis of cells in various manner. GEF-H1/RhoA is a common pathway. We wondered whether miR-194 inhibited the metastasis of A375 cells by suppressing GEF-H1/RhoA 
A

B

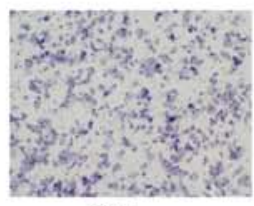

Con

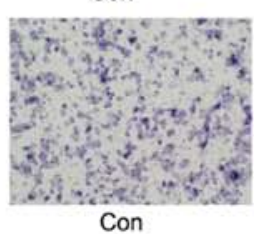

C

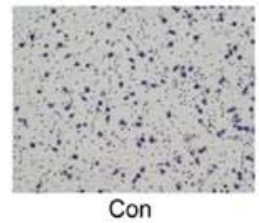

D

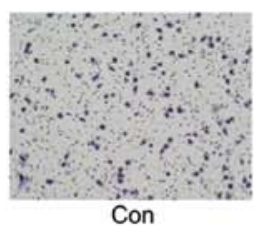

E

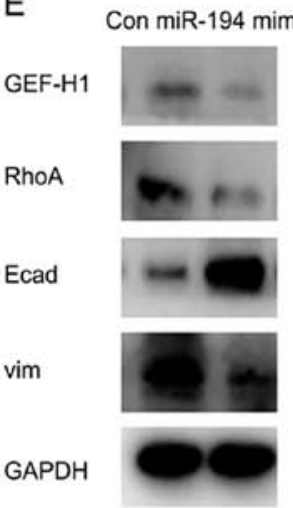

G

GEF-H1

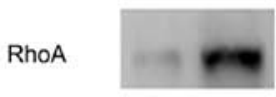

Ecad

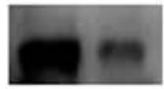

vim

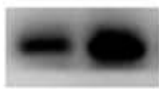

GAPDH

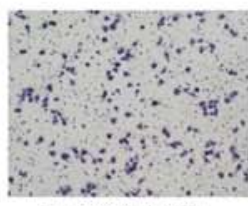

miR-194 mimic

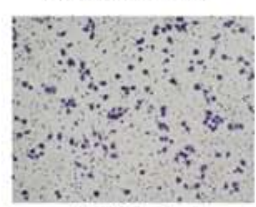

miR-194 mimic
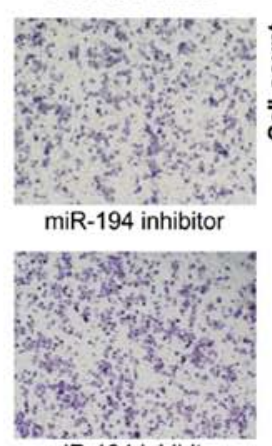

miR-194 inhibitor
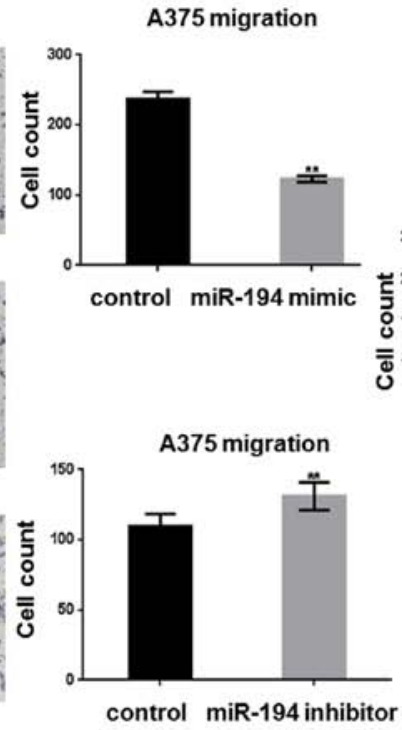

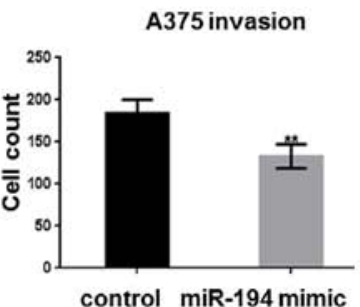

A375 invasion

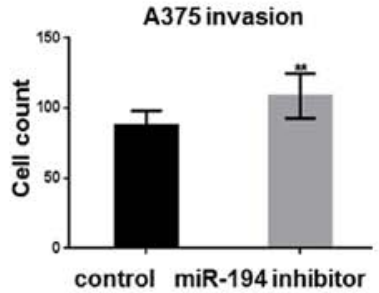

F

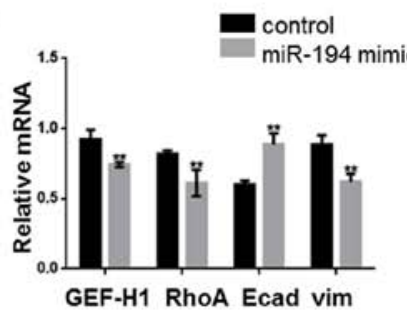

$\mathrm{H}$

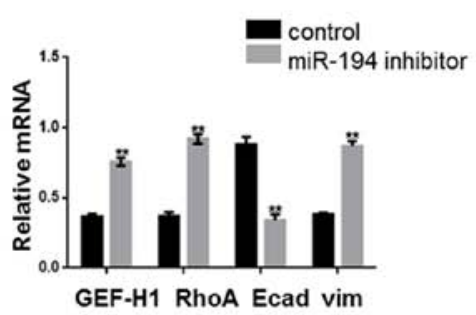

Figure 4. miR-194 inhibits the metastasis of melanoma cells by suppressing GEF-H1/RhoA pathway. (A and B) After overexpression of miR-194 in A375 cells, Transwell assay with or without Matrigel were performed. Cells were counted and results represent the mean \pm SD of three experiments; ${ }^{* *} \mathrm{p}<0.01$. (C and D) After downregulation of miR-194 in A375 cells, Transwell assay with or without Matrigel were performed. Cells were counted and results represent the mean \pm SD of three experiments; ** $p<0.01$. (E and F) A375 cells were overexpressed with miR-194, then detected the indicated proteins, and mRNA by western blotting and real-time PCR. Data are shown as mean \pm SEM; ${ }^{* *} \mathrm{p}<0.01$. (G and H) A375 cells were downregulated with miR-194, the indicated proteins and mRNA levels were detected by western blotting and real-time PCR. Data are shown as mean \pm SEM; ${ }^{* *} p<0.01$.

pathway. We used Transwell assay (with or without Matrigel) to study whether miR-194 is involved in metastasis of A375 cells (Fig. 4A-D). Results showed that the invasion and migra- tion of the A375 cells were significantly inhibited when miR-194 was overexpressed, whereas the invasion and migration of A375 cells were promoted when miR-194 expression was decreased. 
In addition, through western blotting and real-time PCR we found Ecad and vim were significantly downregulated by miR-194 through GEF-H1/RhoA pathway (Fig. 4E-H). These experiments confirmed that miR-194 inhibited the metastasis of melanoma cells by inhibiting the GEF-H1/RhoA pathway.

\section{Discussion}

GEF-H1 affects the occurrence and development of a tumor by regulating tumor cell migration, promotes the proliferation of tumor cells and inhibits the apoptosis of tumor cells (19). It has been reported that GEF-H1 is highly expressed in breast and prostate cancer, myeloid cell tumor and metastatic melanoma, but there were few studies concerning the expression of GEF-H1 in melanoma $(10,19,20)$. GEF-H1 promotes the metastasis of breast cancer cells by inducing the rearrangement of cytoskeleton (20). In prostate cancer cells GEF-H1 participate in the formation of lamellipodia to promote the migration of cells (44). GEF-H1 plays a role in promoting tumor cell growth and invasion and metastasis by regulating the expression of RhoA, and then affects the downstream pathway (18).

In colorectal, gastric and non-small cell lung cancer, miR-194 was proved to be able to inhibit the occurrence and development of tumor $(42,45-47)$. Studies have shown that overexpression of miR-194 inhibited cell proliferation and metastasis by targeting proteins such as RBX1 and BMI1 (42,48). However, we first demonstrated that miR-194 inhibited the growth and metastasis of melanoma by inhibiting the GEF-H1/RhoA pathway.

In the present study, real-time PCR assay showed that the expression of GEF-H1 in the melanoma tissue was $27.62 \%$ higher than that in the adjacent tissues, however, the expression of miR-194 was $29.97 \%$ lower in tumor tissues than the adjacent tissues. Moreover, we found that miR-194 negatively regulates the expression of GEF-H1, and their correlation formula is $\mathrm{y}=-0.4054 \mathrm{x} \mathrm{x}+0.8377 \mathrm{R}^{2}=0.5777$. Furthermore, we overregulated or downregulated the expression of miR-194 in melanoma cells, then detected the functions of miR-194 in melanoma cells through the MTT and Transwell assays. We found that miR-194 inhibited the proliferation and invasion of melanoma cells by inhibiting the expression of GEF-H1. In addition, western blotting and real-time PCR showed that miR-194 depresses the expression of Ecad and promotes the expression of p21 which are the proteins in GEF-H1/RhoA pathway.

In conclusion, our studies have demonstrated that miR-194 is closely related to the occurrence and development of melanoma. miR-194 inhibited the proliferation and invasion of melanoma cells by negative regulation the expression of GEF-H1. Clinically, miR-194 expression may be associated with melanoma TNM grade as well as the prognosis of melanoma. In summary, our findings suggest that miR-194 may be considered in targeted therapy in melanoma.

\section{References}

1. Demierre MF and Merlino G: Chemoprevention of melanoma Curr Oncol Rep 6: 406-413, 2004.

2. Friedman AA, Amzallag A, Pruteanu-Malinici I, Baniya S, Cooper ZA, Piris A, Hargreaves L, Igras V, Frederick DT, Lawrence DP, et al: Landscape of targeted anti-cancer drug synergies in melanoma identifies a novel BRAF-VEGFR/PDGFR combination treatment. PLoS One 10: e0140310, 2015.
3. Achiwa Y, Hasegawa K and Udagawa Y: Effect of ursolic acid on MAPK in cyclin D1 signaling and RING-type E3 ligase (SCF E3s) in two endometrial cancer cell lines. Nutr Cancer 65: 1026-1033, 2013.

4. Ascierto PA, Atkins M, Bifulco C, Botti G, Cochran A Davies M, Demaria S, Dummer R, Ferrone S, Formenti S, et al: Future perspectives in melanoma research: Meeting report from the 'Melanoma Bridge': Napoli, December 3rd-6th 2014. J Transl Med 13: 374, 2015.

5. Aijaz S, D'Atri F, Citi S, Balda MS and Matter K: Binding of GEF-H1 to the tight junction-associated adaptor cingulin results in inhibition of Rho signaling and G1/S phase transition. Dev Cell 8: 777-786, 2005.

6. Hiyoshi H, Okada R, Matsuda S, Gotoh K, Akeda Y, Iida T and Kodama T: Interaction between the type III effector VopO and GEF-H1 activates the RhoA-ROCK pathway. PLoS Pathog 11: e1004694, 2015.

7. Song EH, Oh W, Ulu A, Carr HS, Zuo Y and Frost JA: Acetylation of the RhoA GEF Net1A controls its subcellular localization and activity. J Cell Sci 128: 913-922, 2015.

8. Guilluy C, Swaminathan V, Garcia-Mata R, O'Brien ET, Superfine R and Burridge K: The Rho GEFs LARG and GEF-H1 regulate the mechanical response to force on integrins. Nat Cell Biol 13: 722-727, 2011.

9. Huynh TK, Meeus P, Cassier P, Bouché O, Lardière-Deguelte S, Adenis A, André T, Mancini J, Collard O, Montemurro M, et al: Primary localized rectal/pararectal gastrointestinal stromal tumors: Results of surgical and multimodal therapy from the French Sarcoma group. BMC Cancer 14: 156, 2014.

10. Ridgway LD, Wetzel MD, Ngo JA, Erdreich-Epstein A and Marchetti D: Heparanase-induced GEF-H1 signaling regulates the cytoskeletal dynamics of brain metastatic breast cancer cells. Mol Cancer Res 10: 689-702, 2012.

11. Guo F, Tang J, Zhou Z, Dou Y, Van Lonkhuyzen D, Gao C and Huan J: GEF-H1-RhoA signaling pathway mediates LPS-induced NF- $\kappa \mathrm{B}$ transactivation and IL-8 synthesis in endothelial cells. Mol Immunol 50: 98-107, 2012.

12. Ridgway LD, Wetzel MD and Marchetti D: Modulation of GEF-H1 induced signaling by heparanase in brain metastatic melanoma cells. J Cell Biochem 111: 1299-1309, 2010.

13. Cullis J, Meiri D, Sandi MJ, Radulovich N, Kent OA, Medrano M, Mokady D, Normand J, Larose J, Marcotte R, et al: The RhoGEF GEF-H1 is required for oncogenic RAS signaling via KSR-1. Cancer Cell 25: 181-195, 2014.

14. Gawlak G, Tian Y, O'Donnell JJ III, Tian X, Birukova AA and Birukov KG: Paxillin mediates stretch-induced Rho signaling and endothelial permeability via assembly of paxillinp42/44MAPK-GEF-H1 complex. FASEB J 28: 3249-3260, 2014.

15. Huang IH, Hsiao CT, Wu JC, Shen RF, Liu CY, Wang YK, Chen YC, Huang CM, del Álamo JC, Chang ZF, et al: GEF-H1 controls focal adhesion signaling that regulates mesenchymal stem cell lineage commitment. J Cell Sci 127: 4186-4200, 2014.

16. Kakiashvili E, Dan Q, Vandermeer M, Zhang Y, Waheed F, Pham M and Szászi K: The epidermal growth factor receptor mediates tumor necrosis factor-alpha-induced activation of the ERK/GEF-H1/RhoA pathway in tubular epithelium. J Biol Chem 286: 9268-9279, 2011.

17. Kakiashvili E, Speight P, Waheed F, Seth R, Lodyga M, Tanimura S, Kohno M, Rotstein OD, Kapus A and Szászi K: GEF-H1 mediates tumor necrosis factor-alpha-induced Rho activation and myosin phosphorylation: Role in the regulation of tubular paracellular permeability. J Biol Chem 284: 11454-11466, 2009.

18. Mizuarai S, Yamanaka K and Kotani H: Mutant p53 induces the GEF-H1 oncogene, a guanine nucleotide exchange factor-H1 for RhoA, resulting in accelerated cell proliferation in tumor cells. Cancer Res 66: 6319-6326, 2006.

19. Biondini M, Duclos G, Meyer-Schaller N, Silberzan P, Camonis J and Parrini MC: RalB regulates contractility-driven cancer dissemination upon TGF $\beta$ stimulation via the RhoGEF GEF-H1. Sci Rep 5: 11759, 2015.

20. Liao YC, Ruan JW, Lua I, Li MH, Chen WL, Wang JR, Kao RH and Chen JH: Overexpressed hPTTG1 promotes breast cancer cell invasion and metastasis by regulating GEF-H1/RhoA signalling. Oncogene 31: 3086-3097, 2012.

21. Krendel M, Zenke FT and Bokoch GM: Nucleotide exchange factor GEF-H1 mediates cross-talk between microtubules and the actin cytoskeleton. Nat Cell Biol 4: 294-301, 2002. 
22. Matsuzawa T, Kuwae A, Yoshida S, Sasakawa C and Abe A Enteropathogenic Escherichia coli activates the RhoA signaling pathway via the stimulation of GEF-H1. EMBO J 23: 3570-3582, 2004.

23. Ren Y, Li R, Zheng Y and Busch H: Cloning and characterization of GEF-H1, a microtubule-associated guanine nucleotide exchange factor for Rac and Rho GTPases. J Biol Chem 273: 34954-34960, 1998.

24. Aznar S, Fernández-Valerón P, Espina C and Lacal JC: Rho GTPases: Potential candidates for anticancer therapy. Cancer Lett 206: 181-191, 2004.

25. Erhard F, Haas J, Lieber D, Malterer G, Jaskiewicz L, Zavolan M, Dölken L and Zimmer R: Widespread context dependency of microRNA-mediated regulation. Genome Res 24: 906-919, 2014.

26. Suzuki HI, Mihira H, Watabe T, Sugimoto K and Miyazono K: Widespread inference of weighted microRNA-mediated gene regulation in cancer transcriptome analysis. Nucleic Acids Res 41: e62, 2013.

27. Krol J, Loedige I and Filipowicz W: The widespread regulation of microRNA biogenesis, function and decay. Nat Rev Genet 11: 597-610, 2010.

28. Bennett PE, Bemis L, Norris DA and Shellman YG: miR in melanoma development: miRNAs and acquired hallmarks of cancer in melanoma. Physiol Genomics 45: 1049-1059, 2013.

29. Müller DW and Bosserhoff AK: Integrin beta 3 expression is regulated by let-7a miRNA in malignant melanoma. Oncogene 27: 6698-6706, 2008.

30. Chen J, Feilotter HE, Paré GC, Zhang X, Pemberton JG, Garady C, Lai D, Yang X and Tron VA: MicroRNA-193b represses cell proliferation and regulates cyclin D1 in melanoma. Am J Pathol 176: 2520-2529, 2010.

31. Dar AA, Majid S, de Semir D, Nosrati M, Bezrookove V and Kashani-Sabet M: miRNA-205 suppresses melanoma cell proliferation and induces senescence via regulation of E2F1 protein. J Biol Chem 286: 16606-16614, 2011.

32. Noguchi S, Iwasaki J, Kumazaki M, Mori T, Maruo K, Sakai H, Yamada N, Shimada K, Naoe T, Kitade Y, et al: Chemically modified synthetic microRNA-205 inhibits the growth of melanoma cells in vitro and in vivo. Mol Ther 21: 1204-1211, 2013.

33. Meng Z, Fu X, Chen X, Zeng S, Tian Y, Jove R, Xu R and Huang W: miR-194 is a marker of hepatic epithelial cells and suppresses metastasis of liver cancer cells in mice. Hepatology 52: 2148-2157, 2010

34. Braun CJ, Zhang X, Savelyeva I, Wolff S, Moll UM, Schepeler T, Ørntoft TF, Andersen CL and Dobbelstein M: p53-Responsive micrornas 192 and 215 are capable of inducing cell cycle arrest. Cancer Res 68: 10094-10104, 2008.

35. Song Y, Zhao F, Wang Z, Liu Z, Chiang Y, Xu Y, Gao P and $\mathrm{Xu} \mathrm{H}$ : Inverse association between miR-194 expression and tumor invasion in gastric cancer. Ann Surg Oncol 19 (Suppl 3): S509-S517, 2012.
36. Kemper K, Krijgsman O, Cornelissen-Steijger P, Shahrabi A, Weeber F, Song JY, Kuilman T, Vis DJ, Wessels LF, Voest EE, et al: Intra- and inter-tumor heterogeneity in a vemurafenibresistant melanoma patient and derived xenografts. EMBO Mol Med 7: 1104-1118, 2015.

37. Feng J, Wang K, Liu X, Chen S and Chen J: The quantification of tomato microRNAs response to viral infection by stem-loop real-time RT-PCR. Gene 437: 14-21, 2009.

38. Chen C, Ridzon DA, Broomer AJ, Zhou Z, Lee DH, Nguyen JT, Barbisin M, Xu NL, Mahuvakar VR, Andersen MR, et al: Real-time quantification of microRNAs by stem-loop RT-PCR. Nucleic Acids Res 33: e179, 2005.

39. Pfaffl MW: A new mathematical model for relative quantification in real-time RT-PCR. Nucleic Acids Res 29: e45, 2001.

40. Yang TS, Yang XH, Wang XD, Wang YL, Zhou B and Song ZS: MiR-214 regulate gastric cancer cell proliferation, migration and invasion by targeting PTEN. Cancer Cell Int 13: 68, 2013.

41. Patel D and Chaudhary J: Increased expression of bHLH transcription factor E2A (TCF3) in prostate cancer promotes proliferation and confers resistance to doxorubicin induced apoptosis. Biochem Biophys Res Commun 422: 146-151, 2012.

42. Chen X, Wang Y, Zang W, Du Y, Li M and Zhao G: miR-194 targets RBX1 gene to modulate proliferation and migration of gastric cancer cells. Tumour Biol 36: 2393-2401, 2015.

43. Balch CM, Gershenwald JE, Soong SJ, Thompson JF, Atkins MB, Byrd DR, Buzaid AC, Cochran AJ, Coit DG, Ding S, et al: Final version of 2009 AJCC melanoma staging and classification. J Clin Oncol 27: 6199-6206, 2009.

44. Wells CM, Whale AD, Parsons M, Masters JR and Jones GE: PAK4: A pluripotent kinase that regulates prostate cancer cell adhesion. J Cell Sci 123: 1663-1673, 2010.

45. Basati G, Razavi AE, Pakzad I and Malayeri FA: Circulating levels of the miRNAs, miR-194, and miR-29b, as clinically useful biomarkers for colorectal cancer. Tumour Biol 37: 1781-1788, 2016.

46. Wang B, Shen ZL, Gao ZD, Zhao G, Wang CY, Yang Y, Zhang JZ, Yan YC, Shen C, Jiang KW, et al: MiR-194, commonly repressed in colorectal cancer, suppresses tumor growth by regulating the MAP4K4/c-Jun/MDM2 signaling pathway. Cell Cycle 14: 1046-1058, 2015.

47. Wu X, Liu T, Fang O, Leach LJ, Hu X and Luo Z: miR-194 suppresses metastasis of non-small cell lung cancer through regulating expression of $\mathrm{BMP} 1$ and $\mathrm{p} 27^{\mathrm{kip} 1}$. Oncogene 33: 1506-1514, 2014

48. Dong P, Kaneuchi M, Watari H, Hamada J, Sudo S, Ju J and Sakuragi N: MicroRNA-194 inhibits epithelial to mesenchymal transition of endometrial cancer cells by targeting oncogene BMI-1. Mol Cancer 10: 99, 2011. 